\title{
Deleterious Effect of Urografin on the Renal Tubules of Adult Albino Rats and the Possible Protective Effect of N-Acetylcysteine Light and Electron Microscopic Study
} Original

\author{
Rabab M. Amer ${ }^{1}$ and Sheren S. Elabd ${ }^{2}$
}

${ }^{1}$ Anatomy Department, ${ }^{2}$ Histology Department, Faculty of Medicine, Tanta University

\begin{abstract}
Introduction: Urografin (UG) is one of several types of contrast media used through the extensive use of investigations as imaging and interventional procedures. Multiple complications were encountered from its usage especially kidney affection, in a condition described as Contrast-induced nephropathy (CIN) which may be prevented with the antioxidant N-Acetylcysteine (NAC).

Aim of the work: To study the effect of Urografin on the renal tubules of albino rats and evaluate the role of N-Acetylcysteine administration on the injured tubules.

Materials and Methods: Twenty four adult albino rats were used regardless sex and were divided into 4 groups; a control group, NAC group by its administration in a dose equivalent to the human dose twice daily, Urografin group; where rats received a high dose of Urografin $76 \%$ solution through rat tail vein infusion and UG + NAC group; where rats received the same dose of Urografin 76\% and NAC. The obtained specimens were examined by both light and electron microscopy.

Results: NAC group showed the same normal histological picture of renal tubules as the control group I. Renal sections of UG group revealed tubular dilatation with the presence of cellular debris in their lumens. Some tubules showed destruction and displayed highly vacuolated cytoplasm and dark pyknotic nuclei. Ultrastructurally, damaged apical membrane with partial loss of microvilli and rarefaction of the cytoplasm were noticed. UG + NAC group showed evidence of improvement as compared to UG group. Most of the tubules showed a nearly normal histological picture except for a few dilated ones with cellular debris.

Conclusion: N-Acetylcysteine exerts a protective effect against renal tubular damage of the kidney that has been induced by Urografin injection. So, it may be a useful protective agent before and during imaging procedures.
\end{abstract}

Received: 05 February 2018, Accepted: 30 March 2019

Key Words: N-Acetylcysteine, rats, renal tubules, urografin.

Corresponding Author: Rabab M. Amer, MD, Anatomy Department, Faculty of Medicine, Tanta University, Egypt, ORCID ID: 0000-0003-2794-360X, Tel.: +2 040 3297331, E-mail: rabab_amer2003@yahoo.com - rabab.amer@med.tanta.edu.eg

ISSN: 1110-0559, Vol. 42, No. 3

\section{INTRODUCTION}

The extensive use of investigations as imaging and interventional procedures is widely used all over the world to help in diagnostic and therapeutic purposes. This is associated with an increase in the use of contrast agents specially after the use of Contrast Media CM which began in medicine in the early $1950 \mathrm{~s}^{[1]}$.

Several types of contrast media (CM) vary in their chemical and physiological properties which determine their application. Iodine-based contrast media increases the attenuation of X-ray beams, so they are frequently used for computed tomography (CT). Gadolinium-based contrast agents are frequently used for magnetic resonance imaging $(\mathrm{MRI})^{[2,3]}$

Iodinated contrast media is a substance that can be given by intravenous route during X-ray based radiographic diagnosis. Their uses help in vascular and organs visibility ${ }^{[4]}$. The Contrast Media CM go through the circulation then ,it is eliminated from the body after 24 hours through glomerular filtration in case of normal kidney functions ${ }^{[5]}$.

Unfortunately, like most other drugs, complications may follow the administration of $\mathrm{CM}$. These complications usually affect the kidney because it is responsible for elimination of more than $90 \%$ of the media from the blood. This kidney affection is commonly described as Contrast-induced nephropathy (CIN) which can be defined as a complex form of acute kidney injury with an acute reduction in renal functions, but it might be reversible in some patients ${ }^{[6]}$

The frequency of CIN increases in risk patients as those with hypertension, diabetes, renal insufficiency, old age and with concomitant administration of drugs that interfere with the renal perfusion, such as angiotensin-converting enzyme inhibitors. Some reports stated that CIN is linked to be higher with intra-arterial $\mathrm{CM}$ administration than after intravenous administration ${ }^{[7]}$. Also, the concentration and 
time of exposure play a role in its side effects, especially when large doses are used, as in percutaneous cardiac interventions ${ }^{[8]}$.

Urografin is an ionic monomer, high osmolar, radiographic $\mathrm{CM}$. It contains a mixture of sodium amidotrizoate and meglumine amidotrizoate in a proportion of 10:66 in an aqueous solution, so, $1 \mathrm{ml}$ of Urografin $76 \%$ contains $0.1 \mathrm{gm}$ sodium amidotrizoate and $0.66 \mathrm{gm}$ meglumine amidotrizoate. The usual human adult dose of Urografin is $20 \mathrm{ml}$. Increasing the Urografin dose to 50 or $100 \mathrm{ml}$ considerably increases the diagnostic accuracy which is needed in some circumstances. The dose may be increased yet the rate of injection is $20 \mathrm{ml} /$ minute infusion and time should not be less than 5 minutes ${ }^{[9]}$.

Several preventive strategies were planned to avoid CIN, but the precise preventive strategy has not been proven up till now. Studies reported the preventive effects of adrenomedullin, Enalapril maleate, Folic acid and Pioglitazone through its vasodilatory and anti-inflammatory properties, so can prevent the development of $\mathrm{CIN}^{[6]}$. Some authors stated that oral rehydration solution with saline infusion or Statins administration can prevent $\mathrm{CIN}^{[10-12]}$.

Oral administration of the antioxidant N-Acetylcysteine (NAC) reduces the possibility of acute contrast-mediainduced nephropathy ${ }^{[7,13,14]}$. It has a strong antioxidant effects due to the ability of scavenging free reactive oxygen radicals which explain its reno-protective effects ${ }^{[15]}$. It is a safe, inexpensive, and readily available antioxidant that has been proposed as a prophylactic intervention for CIN on top of optimal hydration ${ }^{[16]}$. Therefore, the aim of the present work was to investigate the effect of Urografin on the renal tubules and evaluate the role of $\mathrm{N}$-Acetylcysteine (NAC) administration on them.

\section{MATERIALS AND METHODS}

\section{Experimental animals}

In the present work, twenty four adult albino rats were used regardless sex and of average weight (150-200 grams). The animals were housed in Anatomy department, Faculty of Medicine, Tanta University. They were kept in an appropriate laboratory room with good hygiene and given a balanced diet. All animals were quarantined for 3-days and were inspected once in a day, and unhealthy rats were excluded. The experiment was approved by the local ethical committee of Faculty of Medicine, Tanta University, Egypt. The rats were randomly allocated into the following groups:

\section{Grouping and treatments}

1. Group I (Control group): consisted of 4 rats receiving a single normal saline dose equal to the Urografin dose, via tail vein injection.

2. Group II (NAC group): consisted of 4 rats receiving $\mathrm{N}$-Acetylcysteine (Acetylcysteine effervescent) in a dose equivalent to the human dose twice daily by orogastric gavage for 3 days ${ }^{[13]}$.

3. Group III (UG group): formed of 8 rats received single dose of Urografin $76 \%$ solution, equivalent to the high human dose $(100 \mathrm{ml})$ via tail vein infusion for 5 minutes ${ }^{[17]}$.

4. Group IV (UG + NAC group): consisted of 8 rats received N-Acetylcysteine (NAC) the same as group II. Then, Urografin was injected the same as in group III and NAC was administered again twice for the next 24 hours after Urografin injection $^{[13,18]}$

Urografin (UG) 76\% was obtained from Berlimed S.A. Spain. An ampoule contains $20 \mathrm{ml}(1 \mathrm{ml}$ contains Sodium amidotrizoate $0.1 \mathrm{~g}$ and Melgium amidotrizoate). The human adult high dose of $70 \mathrm{~kg}$ person is $100 \mathrm{mg}$. Rats of groups III and IV were given an equivalent dose in the rat tail vein once by 5 minutes infusion. Then, the rats were kept for another 24 hours after the injection ${ }^{[17]}$.

N-Acetylcysteine (NAC) was obtained from Sedico, Egypt in effervescent form $600 \mathrm{mg}$ per sachet. Rats of groups II and IV were given an equivalent dose of the human $70 \mathrm{~kg}$ adult dose $600 \mathrm{mg}$ twice daily for 3 days by oral route before Urografin injection and for 24 hours after. The dose of Urografin and the oral Acetylcysteine was calculated as follows: Dosage $=(\mathrm{M} \times \mathrm{Wr}) / \mathrm{Wm}$ where $\mathrm{M}=$ the amount of medication, $\mathrm{Wr}=$ weight of rat and $\mathrm{Wm}=$ weight of standard physiological man $(70 \mathrm{~kg})^{[17,18]}$.

\section{Examination Methods}

After 24 hours of Urografin injection of group III and after NAC administration in group IV, rats of the all groups were sacrificed and the kidneys were collected. Half of the specimens were fixed in $10 \%$ formol saline and processed for paraffin blocks and prepared for light microscopic examination with Hematoxylin $(\mathrm{H})$ and Eosin $(\mathrm{E}) \operatorname{stain}^{[19]}$ The other half of the specimens were fixed in $2.5 \%$ buffered glutaraldehyde and then prepared for transmission electron microscopic examination ${ }^{[20]}$.

\section{RESULTS}

All the rats have tolerated both the Urografin and the $\mathrm{N}$-acetylcysteine NAC treatments well, and all of them survived till the experiment have been finished.

\section{Light microscopic study}

Light microscopic examination of H\&E stained sections obtained from groups I\& II (control group\& NAC group) were the same and exhibited the normal histological structure for the renal cortex. The proximal convoluted tubules (PCTs) constitute much of the renal cortex and located near renal corpuscles. They had narrow lumens and were lined by cuboidal epithelial cells with indistinct boundaries and elaborated striated border. The cells had acidophilic granular cytoplasm and rounded vesicular nuclei. The distal convoluted tubules (DCTs) were less encountered than the PCTs. They showed a wide lumen and were lined with short cuboidal cells displaying an 
acidophilic less granular cytoplasm and rounded nuclei with no brush border (Figure 1).

After injection of Urografin in group III (UG group) light microscopic examination of the renal cortex sections stained by H\& E revealed severe destruction and exhibited tubulo-interstitial injuries. Most of the tubules were dilated with the presence of cellular debris in their lumens. Most of the tubular cells had vacuolated cytoplasm and vesicular nuclei. Some tubules revealed destruction of apical plasma membrane with obvious decrease of their height and displaying highly vacuolated cytoplasm and dark pyknotic nuclei. Some cells lost their nuclei whereas other cells were exfoliated in the tubular lumen. Some disparate tubules showed detachment of their basement membrane. Dilated peritubular space, congested capillaries, mononuclear inflammatory cells and inter-tubular hemorrhage were detected (Figures 2-5).

Examination of H\&E stained-sections obtained from the renal cortex of rats treated with Urografin and $\mathrm{N}$ - Acetylcysteine (group IV) revealed evidence of improvement as compared to group III. Most of the tubules showed a nearly normal histological picture except for a few dilated ones with cellular debris in their lumens. Some tubular cells exhibited vacuolated cytoplasm and pyknotic nuclei (Figures 6 and 7).

\section{Electron microscopic study}

Electron microscopic examination of the control\& NAC groups (I, II) revealed cells of the proximal convoluted tubules (PCTs) with apical closely packed long microvilli and basal numerous infoldings enclosing elongated palisade of mitochondria (Figure 8). Cells of the distal convoluted tubules (DCTs) appeared smaller than those of the proximal ones, with few or no microvilli and basal infoldings encompassed the elongated packed mitochondria (Figure 9).

By electron microscopic examination of group III (UG group), the cells of the PCTs showed multiple changes, in the form of damaged apical membrane with partial loss of microvilli. There were no basal infoldings and the mitochondria were disorganized and exhibited different sizes and shapes. In addition, the cytoplasm was rarified with presence of multiple cytoplasmic vacuoles. The nucleus was central with extended chromatin (Figure 10). Some cells appeared ruptured with extrusion of their cytoplasmic organelles into the lumen, as well as loss of basal infoldings (Figure 11). Most of the cells of the DCTs showed interrupted basal infoldings with dispersed pleomorphic mitochondria. Some mitochondria appeared swollen and degenerated with cristolysis. The cytoplasm displayed heterogeneous electron-dense bodies and plenty of cytoplasmic vacuoles. (Figure 12). Some cells revealed destructed apical plasma membrane with lack of microvilli.
These cells showed absence of basal infoldings with abnormal mitochondrial deposition. Several cells exhibited rarified cytoplasm and the nucleus were hyperchromatic with irregular outlines (Figure 13).

Ultrathin sections of the renal cortex of group IV (UG + NAC) confirmed the light microscopic findings revealing a nearly normal renal ultrastructure. The lining epithelium of the convoluted tubules showed nearly normal appearance as rounded euchromatic nuclei and numerous elongated mitochondria in between basal infoldings. Few cells revealed some ultrastructural changes in the form of presence of heterogeneous electron dense bodies and dilatation of intercellular space (Figures 14 and 15). Regarding the DCTs, most cells exhibited a nearly normal appearance (Figure16).

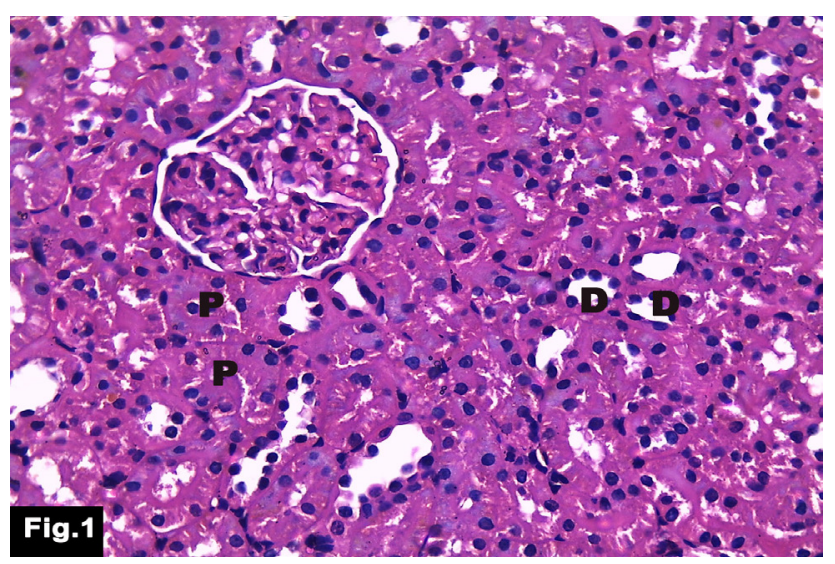

Fig. 1: A photomicrograph of a section in the kidney cortex of contro group showing proximal convoluted tubules $(\mathrm{P})$ with narrow lumens. The cells exhibit indistinct boundaries with apical striated border. The distal convoluted tubules (D) show wide lumens and are lined with short cuboidal cells with no brush border. (H\&E X400)

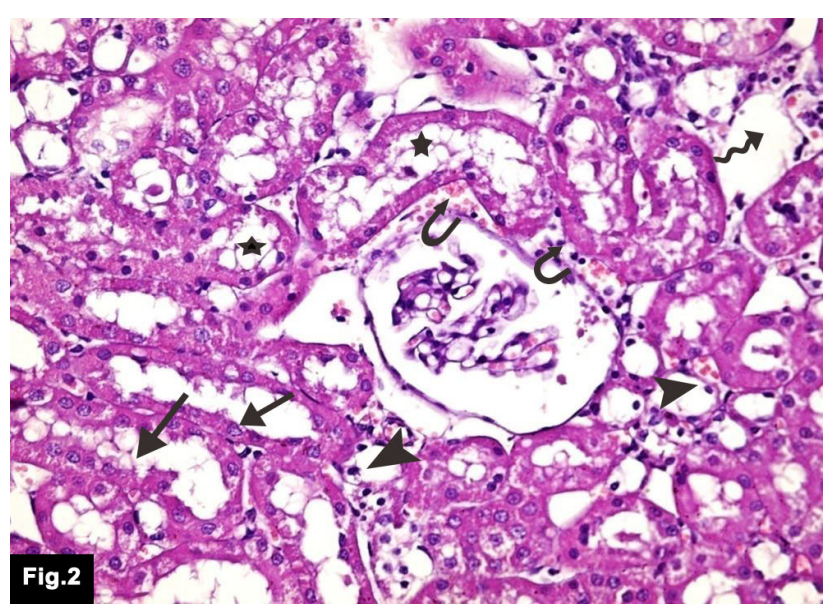

Fig. 2: A photomicrograph of a section in the kidney cortex of group III (UG group) showing dilated renal tubules with cellular debris inside the lumens (stars). The tubular cells have vacuolated cytoplasm and vesicular nuclei (arrows) while, some tubules have decreased cellular heights and pyknotic nuclei (arrow heads). Notice the dilated peritubular space (wavy arrow),peritubular hemorrhage and inflammatory cells (curved arrows). (H\&E X400) 


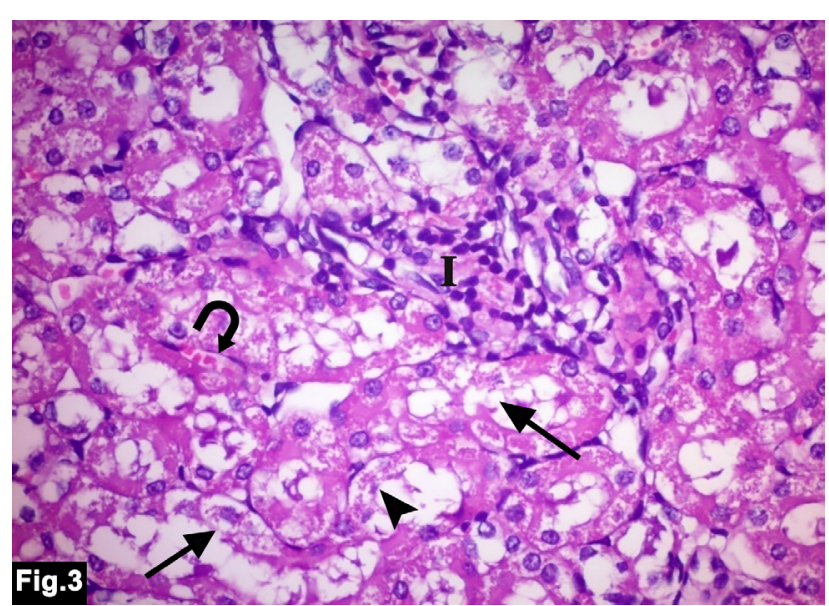

Fig. 3: A photomicrograph of a section in the renal cortex of group III showing severely damaged renal tubules with destructed apical membrane $(\rightarrow)$ and vacuolated cytoplasm. Some tubular cells lose their nuclei $(\downarrow)$. Mononuclear inflammatory cells (I) and congested capillaries (curved arrow) are detected. (H\&EX400)

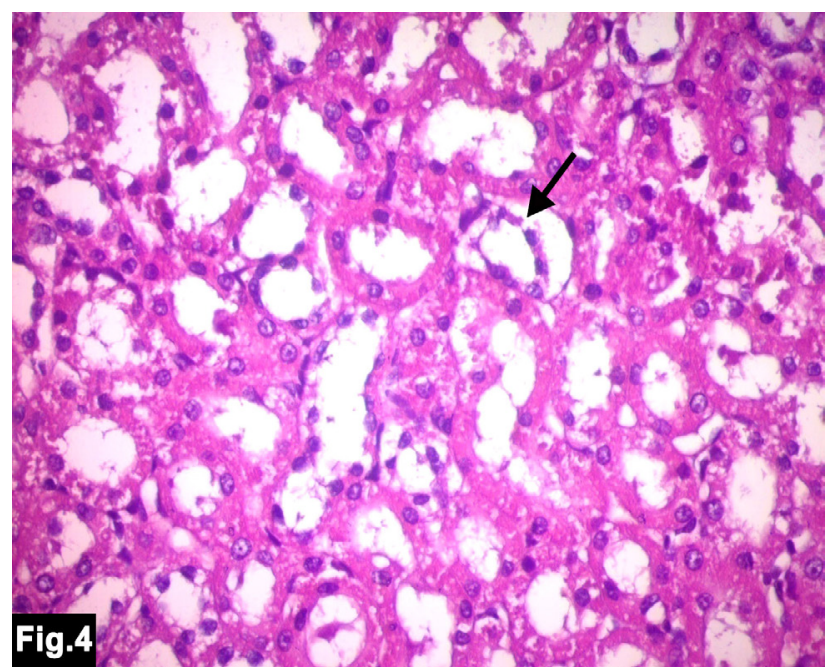

Fig. 4: A photomicrograph of a section in the renal cortex of group III showing disrupted tubular wall with detached basement membrane $(\rightarrow)$. (H\&EX400)

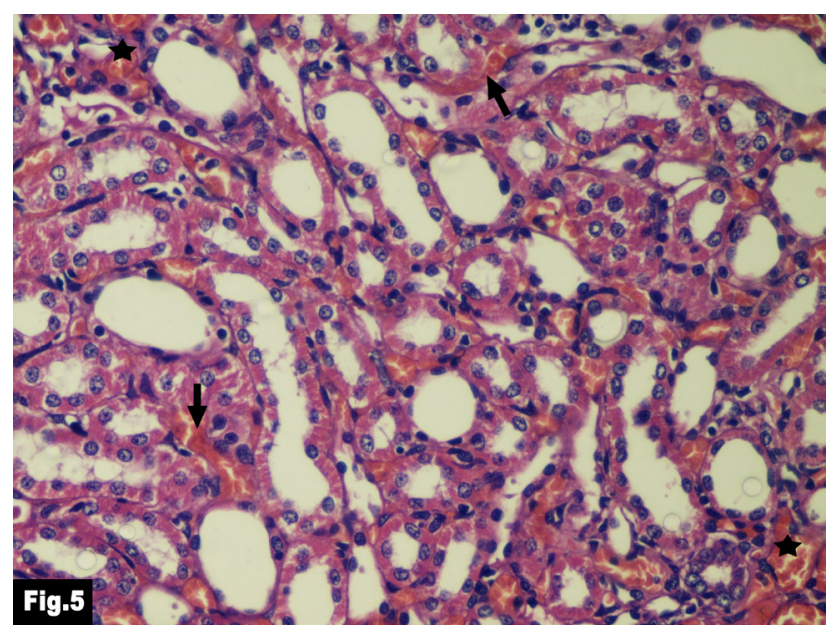

Fig. 5: A photomicrograph of a section in the renal cortex of group III showing congested blood vessels (stars) and intertubular hemorrhage $(\rightarrow)$. (H\&EX400)

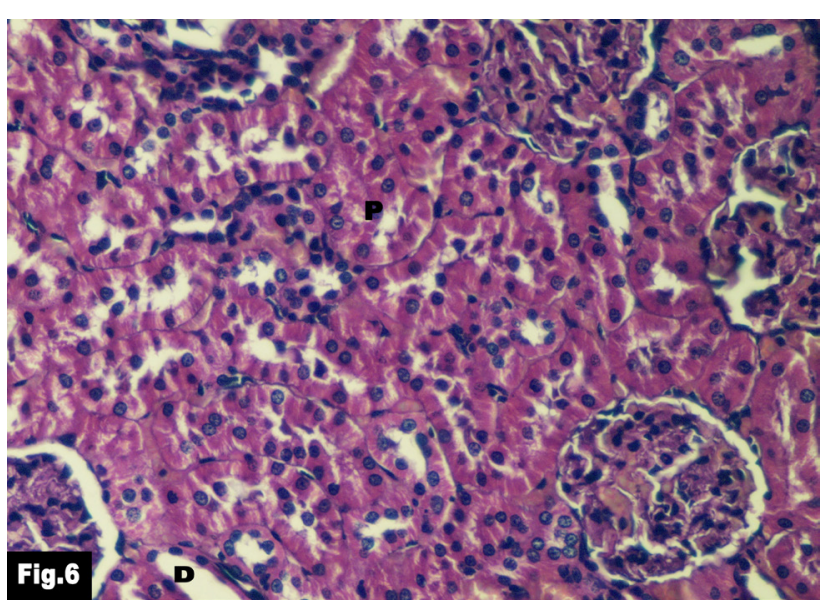

Fig 6: A photomicrograph of a section in the renal cortex of group IV (UG + NAC group) showing, normal proximal convoluted tubules (P) with acidophilic cytoplasm and brush border. The distal convoluted tubules (D) appear normal with wider lumens. (H\&EX400)

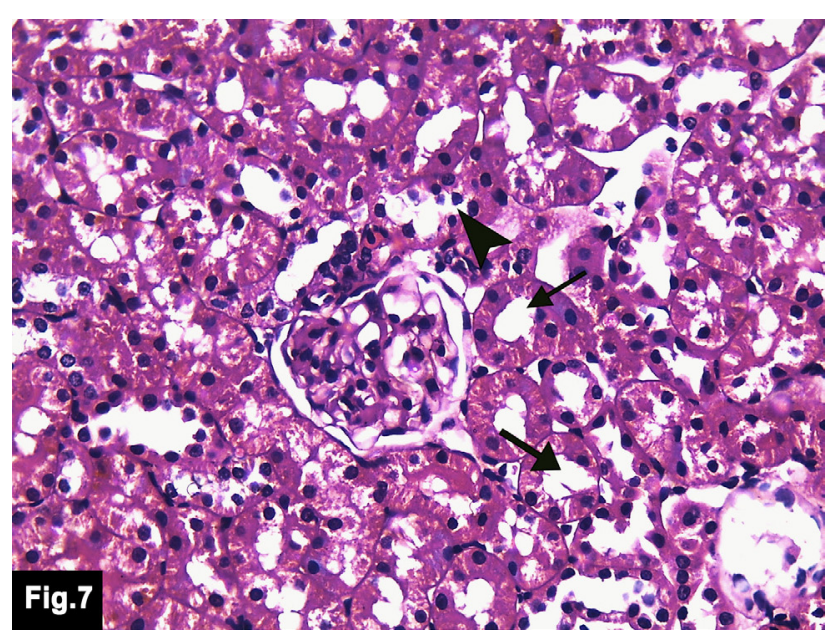

Fig. 7: A photomicrograph of a section in the renal cortex of group IV showing some dilated tubules with vacuolated cytoplasm and pyknotic nuclei $(\rightarrow)$. Few tubules contain intra-tubular cellular debris and detached cells $(\triangleright)$. (H\&EX400)

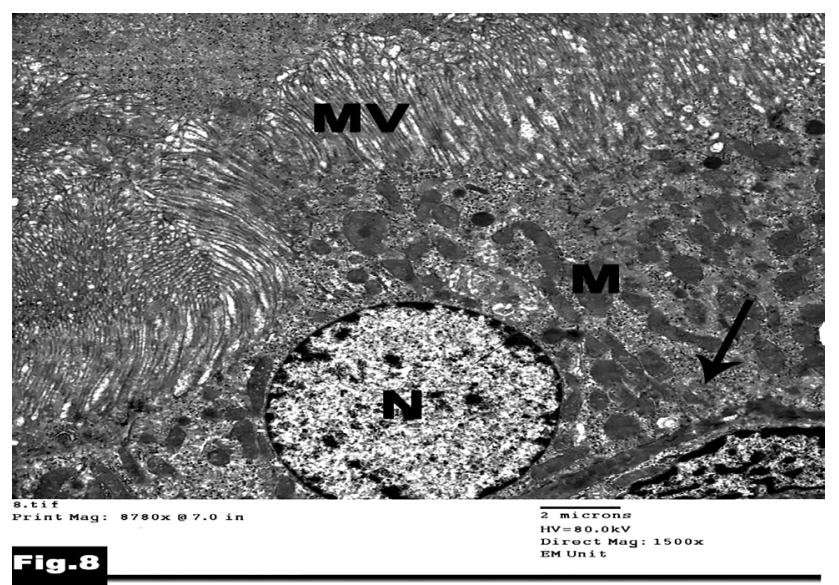

Fig. 8: An electron micrograph of the renal cortex of the control group, showing a cell of proximal convoluted tubule with characteristic apical long microvilli $(\mathrm{Mv})$, characteristic basal infoldings $(\rightarrow)$ containing elongated mitochondria (M) and central rounded nucleus with extended chromatin (N). (Mic. Mag. $\times 1500)$ 


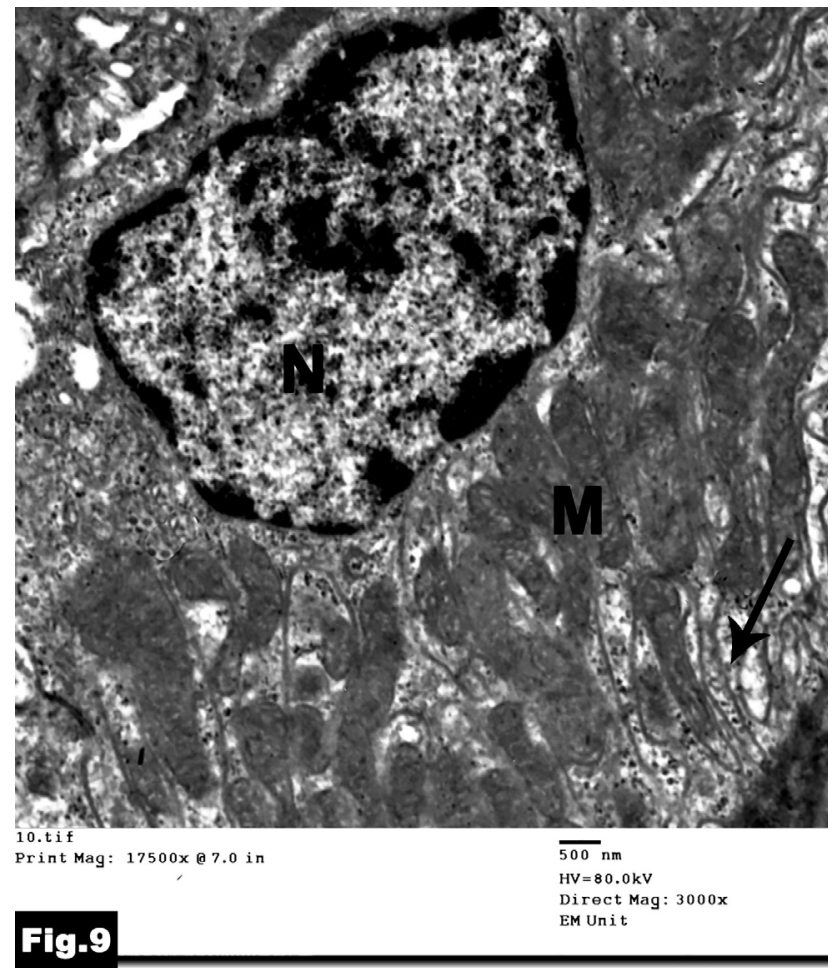

Fig. 9: An electron micrograph of the renal cortex of the control group, showing a cell of distal convoluted tubule with no apical microvilli. Central nucleus exhibiting extended chromatin $(\mathrm{N})$, basal infoldings $(\rightarrow)$ and elongated packed mitochondria in between $(\mathrm{M})$ are noticed. (Mic. Mag. X3000)

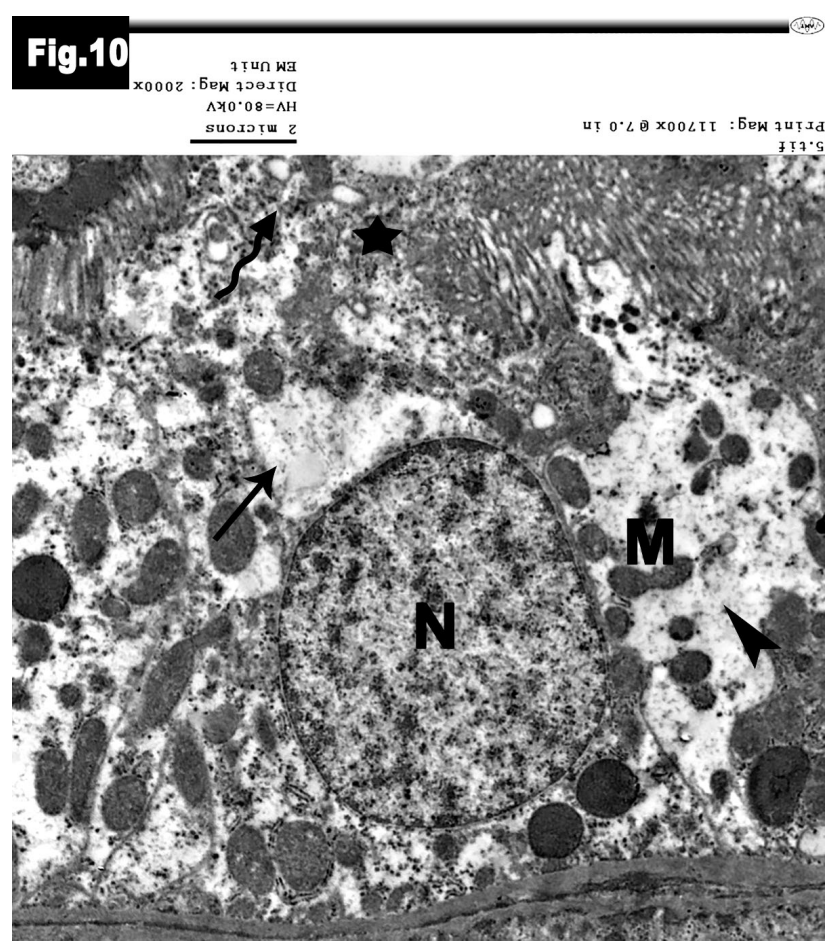

Fig. 10: An electron micrograph of PCT of group III (UG group) showing damaged apical membrane (star) with partial absence of microvilli (wavy arrow)and loss of the basal infoldings. The mitochondria are disorganized and exhibiting different sizes and shapes (M). Notice the rarified cytoplasm $(\downarrow)$, cytoplasmic vacuole $(\rightarrow)$ and the central nucleus with extended chromatin (N). (Mic. Mag.X2000)

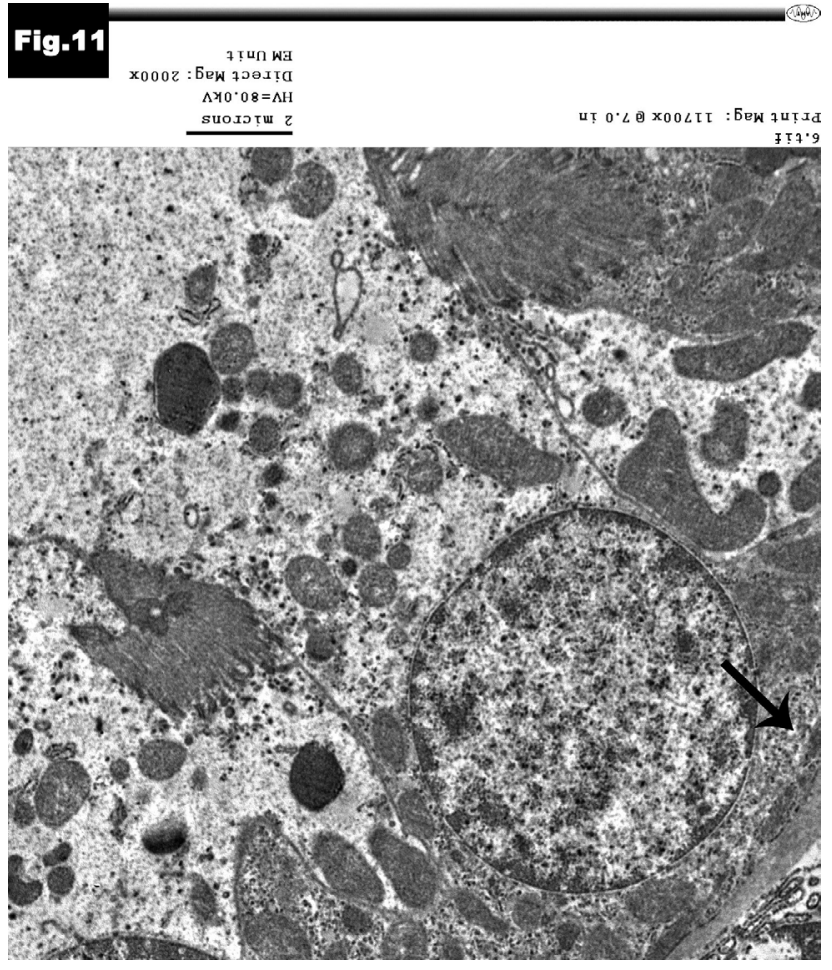

Fig. 11: An electron micrograph of PCT of group III showing ruptured cell with extrusion of cellular organelles and loss of basal infoldings $(\rightarrow)$ (Mic. Mag.X2000)

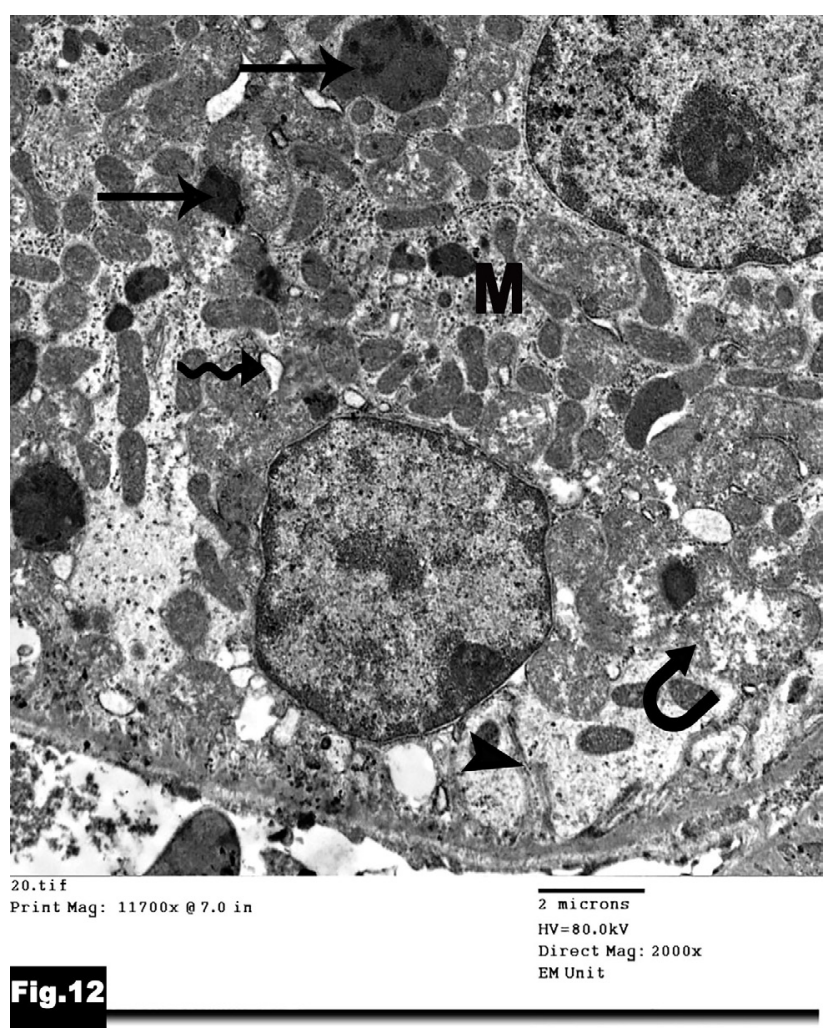

Fig. 12: An electron micrograph of DCT of group III showing interrupted basal infoldings $(\triangleright)$, dispersed pleomorphic mitochondria $(M)$. Some mitochondria appear swollen with cristolysis (curved arrow). Many heterogeneous electron-dense bodies $(\rightarrow)$ and cytoplasmic vacuoles () are observed. (Mic. Mag X 2000) 


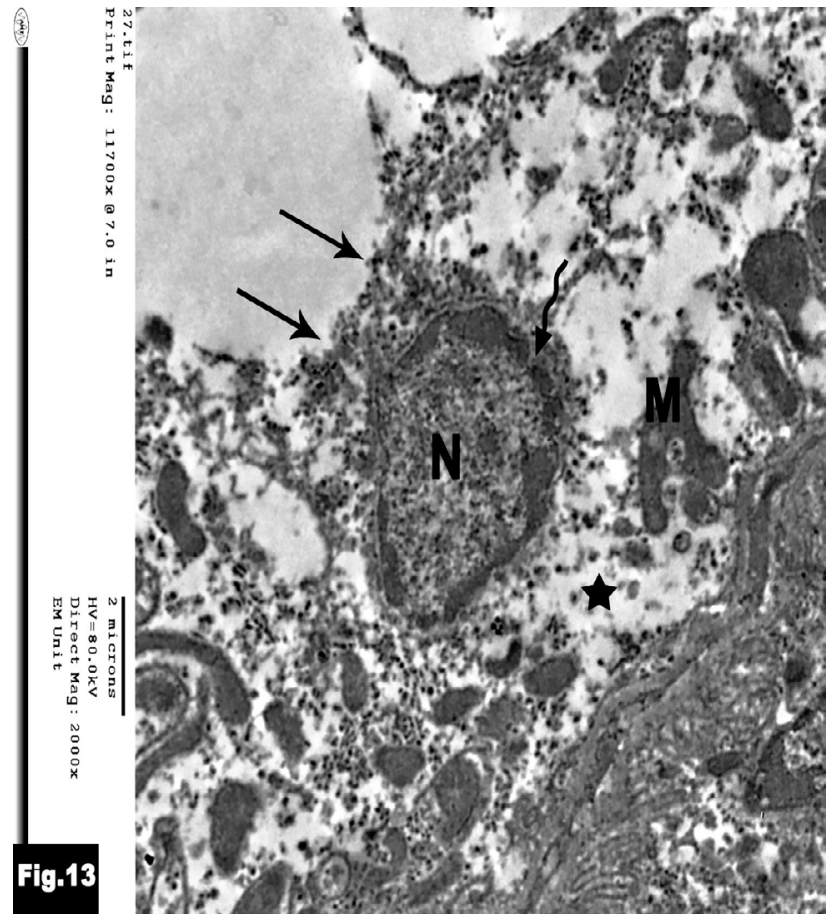

Fig. 13: An electron micrograph of DCT of group III showing rupture of apical plasma membrane $(\rightarrow)$, absence of microvilli, loss of basal infoldings (star) with abnormal arrangement of the pleomorphic mitochondria (M). The cytoplasm is rarified and the nucleus is hyperchromatic $(\mathrm{N})$ with irregular nuclear outline (wavy arrow). (Mic. Mag X 2000)

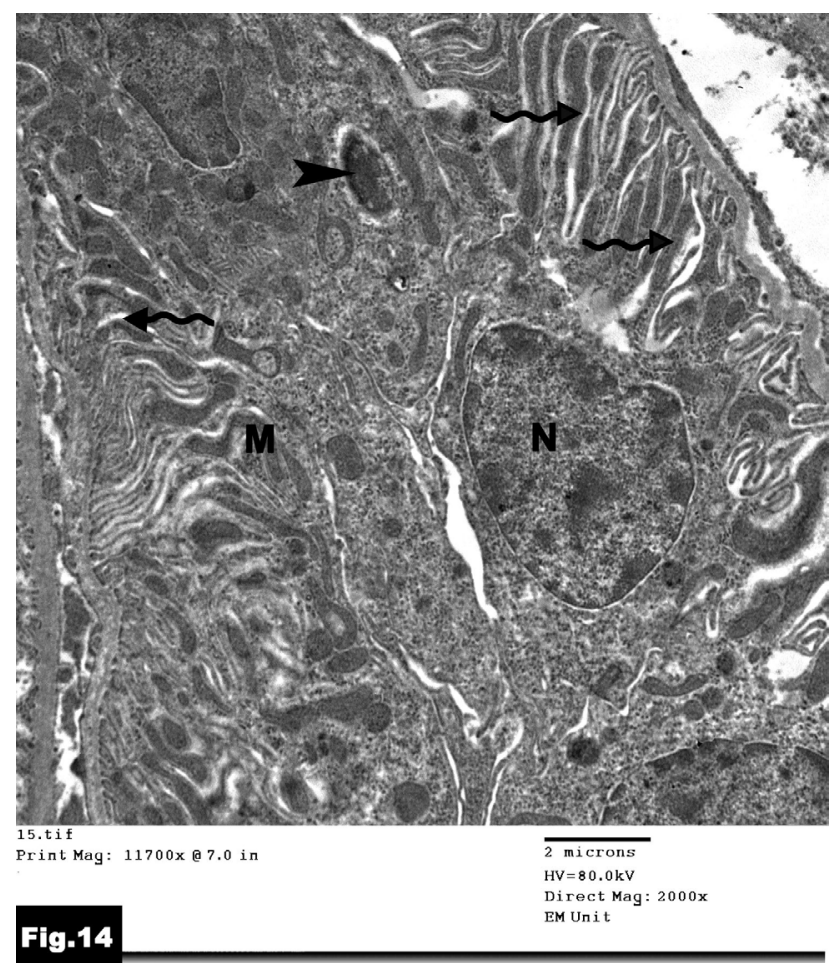

Fig. 14: An electron micrograph of renal cortex of group IV (UG + NAC group) showing renal tubule lining cell with normally rounded nucleus $(\mathrm{N})$, normal basal infoldings (wavy arrows) with elongated mitochondria palisade (M). Notice a heterogeneous electron dense body in the cytoplasm ( ). (Mic. Mag X 2000)

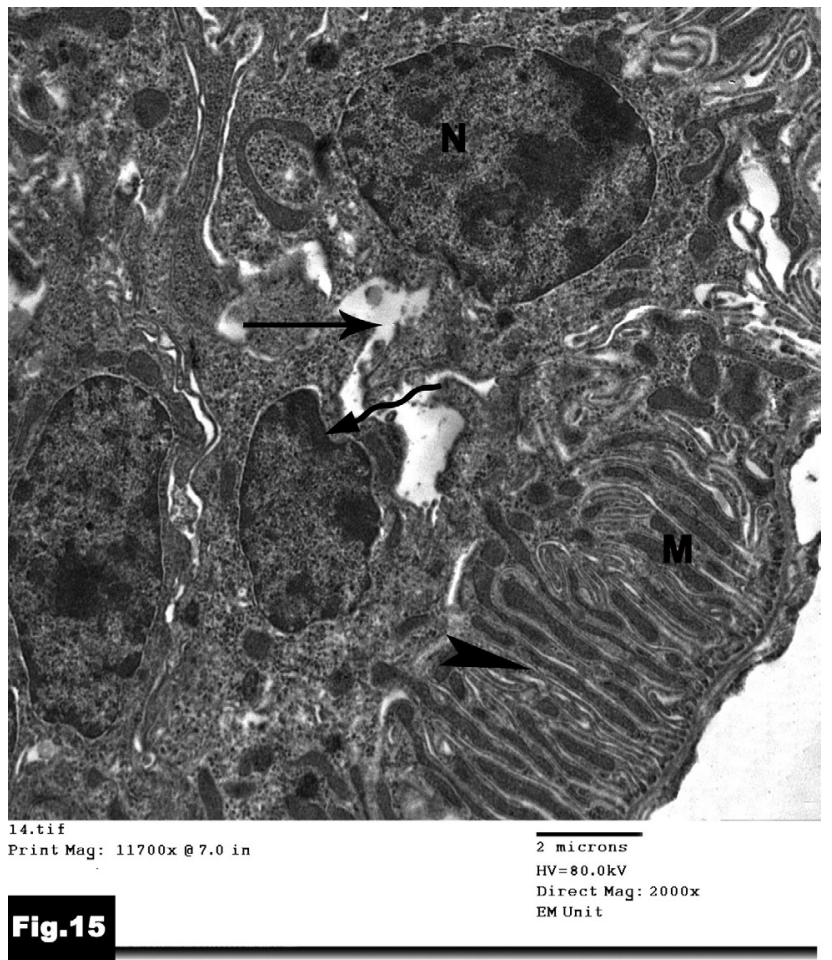

Fig. 15: An electron micrograph of renal cortex of group IV showing the cells lining the convoluted tubules with basal infoldings $(\nabla)$ having longitudinally oriented mitochondria $(\mathrm{M})$ and wide intercellular space $(\rightarrow)$. The nuclei $(\mathrm{N})$ show euchromatic chromatin and few nuclei exhibit irregular outlines (wavy arrow). (Mic. Mag X 2000)

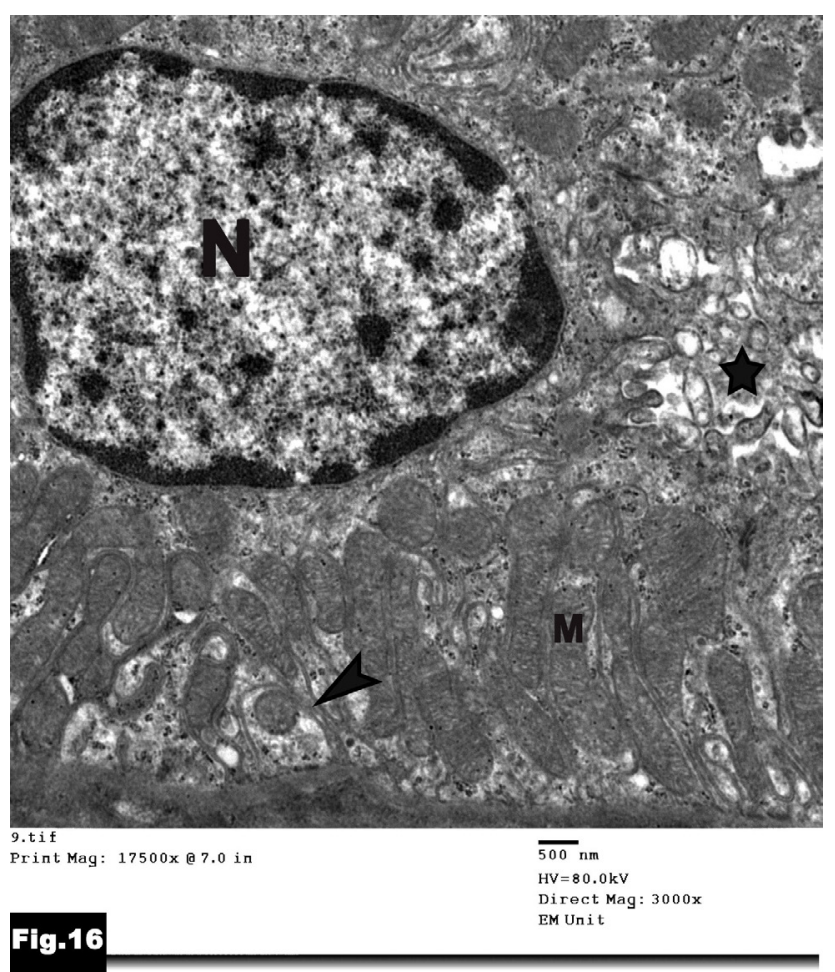

Fig. 16: An electron micrograph of DCT of group IV showing cell with preserved basal infoldings $(\checkmark)$ having a normally oriented mitochondrial palisade (M) and lateral cellular interdigitation (star). The nucleus is central, rounded with extended chromatin (N). (Mic. Mag X 3000) 


\section{DISCUSSION}

Nowadays the extensive use of contrast media for imaging procedures, is unavoidable due to their major importance in medical diagnostic purposes, in spite of their reported side effects on different organs specially the kidney producing contrast-induced nephropathy ${ }^{[21]}$. Therefore, our study attempted to address this problem by using N-Acetylcysteine as a preventive measure from contrast induced nephropathy ${ }^{[22]}$.

In the present study, after Urografin injection, the principal findings were in the form of tubular dilatation, or severe tubular destruction with appearance of intratubular debris. These results coincide with Xia et al. ${ }^{[18]}$ who reported similar changes in the form of collapse of the lumen of kidney tubules, presence of protein and cellular casts in their lumen or severe renal interstitial fibrosis.

In this work, after injection of Urografin, some tubules revealed destruction of the apical plasma membrane with obvious decrease of their height and displaying highly vacuolated cytoplasm with dark pyknotic nuclei. These results are in agreement with Kohli et al. ${ }^{[23]}$ and Xia et al. ${ }^{[18]}$ who reported similar results like destroyed microvilli, vacuolation of cytoplasm and renal tubular damage.

Moreover, the mononuclear inflammatory cells, intertubular hemorrhage and congested peritubular capillaries observed in Urografin group were explained by the strong systemic inflammatory response and the production of inflammatory cytokines in response of contrast media administration $^{[24]}$.

Ultrastructurally, Urografin injection revealed destructed apical membrane with partial loss of microvilli, swollen degenerated mitochondria with cristolysis and plenty of cytoplasmic vacuoles. These changes are in agreement with Emad et al. ${ }^{[25]}$ who reported mitochondrial enlargement (ballooning) with partial to complete loss of their cristae and partial loss of the apical microvilli with vacuolations and rarefaction of the cytoplasm.

In addition, in our results several cells exhibited rarified cytoplasm and hyperchromatic nuclei with irregular outlines. These findings coincide with Romano et al. ${ }^{[26]}$ who reported cellular injury of the renal medulla in the form of extensive DNA fragmentation, and stated that the contrast media induce apoptosis which has been attributed to medullary hypoxia.

Several theories explained the mechanism by which the $\mathrm{CM}$ can induce nephropathy especially high osmolar ones because its high osmolarity is related to acute adverse reactions ${ }^{[3]}$. It may be due to direct cytotoxicity, vasoconstrictive stimuli following the release of prostaglandins and endothelin from endothelial cells exposed to CM. Moreover, Urografin leads to depressed activity of mitochondrial scavengers and enhances the formation of reactive oxygen species (ROS) that threaten oxygen balance and antioxidant functions, and directly cause apoptosis and cell necrosis. Also, vasoconstriction leads to ischemia in renal medulla which increases the amounts of secreted reactive oxygen species(ROS ${ }^{[8,27]}$,

Kohli et al. ${ }^{[23]}$ explained another patho-physiologic mechanism of contrast media induced kidney injury due to the strong systemic inflammatory response from its injection. Another route of kidney injury is hemolysis and release of free hemoglobin, transferrin and haptoglobin, resulting in renal tubular damage. Oxidative stress occurring with $\mathrm{CM}$ increases reactive oxygen species ROS that activate cytokine-induced inflammatory mediators, resulting in damage to proximal tubular cells ${ }^{[28]}$,

As a preventive tool from contrast-induced nephropathy, in the present work we tried to study N-Acetylcysteine protective effect and found that it decreased greatly most of the harmful effects of Urografin on the kidney tubules with apparent improvement in the histological renal picture. These results are in accordance with Xia et al. ${ }^{[18]}$ who stated that Acetylcysteine has apparently decreased apoptosis occurring in renal tubular cells of rats as a response to ureteric obstruction with $\mathrm{CM}$, and ameliorates kidney injury.

Other researchers reported also the protective effect of N-Acetylcysteine against contrast media induced renal damage. Yayla et al. ${ }^{[14]}$ reported its protective effect against nephropathy in patients undergoing coronary angiography. Other studies confirmed the same results in NAC prevention of contrast induced nephropathy in patients undergoing peripheral angiography ${ }^{[29]}$. Other in vitro studies have shown the ability of NAC to protect in a dose-dependent fashion the cultured renal tubular cells incubated with high concentrations of low and high osmolar contrast media ${ }^{[27]}$.

The mechanism by which $\mathrm{N}$ - Acetylcysteine can decrease kidney injury is controversial; it may be through the anti-vasoconstriction function, enhancing renal blood flow and so decrease incidence of cell injury, or may be due to the thiol group of NAC that can deactivate reactive oxygen species and plays antioxidant role directly and decreases the systemic and renal oxidative stress ${ }^{[18]}$.

In conclusion, the administration of N-Acetylcysteine shows promising results in our animal model research and exerts a protective effect against renal tubular damage of the kidney that has been induced by Urografin injection. So, N-Acetylcysteine may be a useful protective agent before the procedure and during it.

\section{CONFLICTS OF INTEREST}

There are no conflicts of interest.

\section{REFERENCES}

1. Buyuklu M, Kandemir FM, Ozkaraca M, Set T, Bakirci EM, Topal E. Protective effect of curcumin against contrast induced nephropathy in rat kidney: what is happening to oxidative stress, inflammation, autophagy and apoptosis. Eur Rev Med Pharmacol Sci. 2014;18(4):461-70. 
2. Nielsen YW, Thomsen HS. Current Evidence of Contrast Medium-Induced Nephropathy (CIN) After Administration of Low-Osmolarity Iodine-Based Contrast Agents. Curr Radiol Rep. 2017;5(10):52.

3. Bucher AM, De Cecco CN, Schoepf UJ, Meinel FG, Krazinski AW, Spearman JV, et al. Is contrast medium osmolality a causal factor for contrastinduced nephropathy? Biomed Res Int. 2014:1-8.

4. Pasternak JJ, Williamson EE,. Clinical pharmacology, uses, and adverse reactions of iodinated contrast agents: a primer for the non-radiologist. Mayo Clin Proc. 2012; 87(4): 390-402.

5. McDonald RJ, McDonald JS, Bida JP, Carter RE, Fleming CJ, Misra S, et al. Intravenous contrast material-induced nephropathy: causal or coincident phenomenon? Radiology. 2013;267(1):106-18.

6. Inal S, Koc E, Ulusal-Okyay G, Pasaoglu ÖT, Isik-Gönül I, Öz-Oyar E, et al. Protective effect of adrenomedullin on contrast induced nephropathy in rats. Nefrologia. 2014;34(6):724-31.

7. Tepel M, Van Der Giet M, Schwarzfeld C, Laufer U, Liermann D, Zidek W. Prevention of radiographic-contrast-agent-induced reductions in renal function by acetylcysteine. N Engl J Med. 2000;343(3):180-4.

8. Sendeski MM. Pathophysiology of renal tissue damage by iodinated contrast media. Clinical and Experimental Pharmacology and Physiology. 2011;38(5):292-9.

9. Ogawa M, Kawaguchi Y, Kawashima Y, Mizukami $\mathrm{H}$, Maruno A, Ito $\mathrm{H}$, et al. Comparison of ionic, monomer, high osmolar contrast media with nonionic, dimer, iso-osmolar contrast media in ERCP. Tokai J Exp Clin Med. 2013;38(3):109-13.

10. Matsunami T, Hino K, Dosho R, Miyatake S, Ebisu G, Kuwatsuru R. Efficacy of oral supplemental hydration for the prevention of contrast-induced nephropathy in rats. Jpn. j. radiol. 2017;4(35): 190-6.

11. Mousleh R, Al Laham S, Al-Manadili A. The Preventive Role of Pioglitazone in GlycerolInduced Acute Kidney Injury in Rats during Two Different Treatment Periods. Iran. J. Med. Sci.. 2018; 43(2):184-94.

12. Hou J, Yan G, Liu B, Zhu B, Qiao Y, Wang D, et al. The Protective Effects of Enalapril Maleate and Folic Acid Tablets against Contrast-Induced Nephropathy in Diabetic Rats. Biomed Res Int. 2018;1-8.

13. Li J, Jin E, Yu L, Li Y, Liu N, Dong Y, et al. Oral $\mathrm{N}$-acetylcysteine for prophylaxis of contrast- induced nephropathy in patients following coronary angioplasty: A meta-analysis. Exp Ther Med. 2017;14(2):1568-76.

14. Yayla Ç, Yayla KG, Ünal S, Açar B, Akboğa MK, Demirtaş K. N-acetylcysteine and contrast-induced nephropathy. Angiology. 2018;69(1):85-92.

15. Droppa M, Desch S, Blase P, Eitel I, Fuernau G, Schuler $\mathrm{G}$, et al. Impact of $\mathrm{N}$-acetylcysteine on contrast-induced nephropathy defined by cystatin $\mathrm{C}$ in patients with ST-elevation myocardial infarction undergoing primary angioplasty. CLIN RES CARDIOL. 2011;100(11):1037.

16. Berwanger O, Cavalcanti AB, Sousa AM, Buehler A, Castello-Júnior HJ, Cantarelli MJ, et al. Acetylcysteine for the prevention of renal outcomes in patients with diabetes mellitus undergoing coronary and peripheral vascular angiography: a substudy of the acetylcysteine for contrast-induced nephropathy trial. Circ. Cardiovasc. Interv.. 2013; 6(2);139-145

17. Ikamaise V.C. ETB, Eduwem D.U3, Paulinus S.O.4 and Archibong B.E. Effects of urografin on the morphology of kidney cells of adult wistar rats. palgo journal of medicine and medical science. 2016; 3 (3): 83 - 90.

18. Xia Q, Liu C, Zheng X. N-acetylcysteine ameliorates contrast induced kidney injury in rats with unilateral hydronephrosis. Mol. Med. Rep.. 2018;17(2):2203-10.

19. Bancroft JD, Layton C, Sauvarna SK. "The Hematoxylins and Eosin"In: Bancroft's Theory and practice of histological technique. 7th Ed. Churchil Livingstone London, England. 2013; PP: 173-186.

20. Kuo J. Electron microscopy: Methods and protocols. Acta Biochim Pol..2007; 56 (1): 195-197.

21. Boyacioglu M, Turgut H, Akgullu C, Eryilmaz U, Kum C, Onbasili OA. The effect of L-carnitine on oxidative stress responses of experimental contrast-induced nephropathy in rats. J VET MED SCI. 2014;76(1):1-8.

22. Tamadon MR, Bahadoram M, Zarghami A, Bahadoram S. Administration of $\mathrm{N}$-acetylcysteine for contrast-induced acute kidney injury; new concepts. Journal of Ischemia and Tissue Repair. 2017;1(1).

23. Kohli J, Sethi AN, Rudnick MR. "Contrast induced nephropathy"In: Cardio-Nephrology: Springer; 2017. p. 347-53.

24. Wang X 1, Zhang T, Hu L H, Sun S Q, Zhang W F, Sun Z, et al. Comparison of Effects of Different Statins on Contrast-Induced Acute Kidney Injury in 
Rats: Histopathological and Biochemical Findings. Oxidative Medicine and Cellular Longevity. 2017.

25. Emad M, El-Sherif ABM, Abd-El Wahed M K, Ahmed R M. Effect of urografin on the kidney of adult female albino rat and the possible protective role of nebivolol: A morphological and ultrastructural study. Life Sci J.2013; 10(4): 248-26.

26. Romano G, Briguori C, Quintavalle C, Zanca C, Rivera NV, Colombo A, et al. Contrast agents and renal cell apoptosis. Eur Heart J. 2008;29(20): 2569-76.

27. Pisani A, Riccio E, Andreucci M, Faga T, Ashour M, Di Nuzzi A, et al. Role of reactive oxygen species in pathogenesis of radiocontrast-induced nephropathy. Biomed Res Int. 2013; 868321.

28. Burgess WP, Walker PJ. Mechanisms of contrastinduced nephropathy reduction for saline $(\mathrm{NaCl})$ and sodium bicarbonate $(\mathrm{NaHCO} 3)$. Biomed Res Int 2014; 6pages.

29. O'sullivan S, Healy D, Moloney MC, Grace P, Walsh S. The role of N--acetylcysteine in the prevention of contrast-induced nephropathy in patients undergoing peripheral angiography: a structured review and meta-analysis. Angiology. 2013;64(8):576-82. 


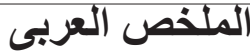

\section{التأثير الضار لعقار اليوروجرافين على الأنابيب الكلوية للفئران

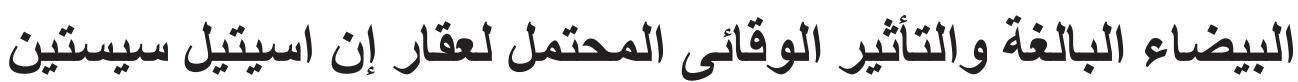

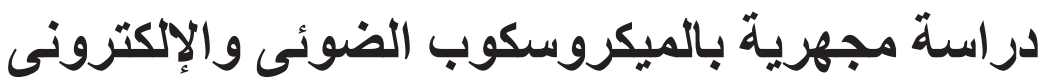

\author{
رباب محمد عامر وشيرين شوقى العبد \\ قسم التشريح الآدمي وعلم الأجنة وقسم الهستولوجيا ـ كلية الطبـ جامعة طنطا
}

مقدمة: يعد عقار اليوروجر افين واحداً من عدة أنو اع من وسائط التباين المستخدمة بصورة مكثفة فى تحقيقات الأمر اض كالتصوير بالأشعة وإجراءات تدخلية أخرى. ولقد تم اكتثاف مضاعفات متعدده من استخدامه وخاصة التأثير على التى الكلى فى ما يوصف باعتلال الكلية الناجم عن وسائط التباين و التى يمكن الوقاية منها باستخدام مضاد الأكسده إن اسيتيل سيستين. الهلف من العمل: هو در اسة تأثير عقار اليوروجر افين على الأنابيب الكلوية للفئر ان البيضاءو تقييم دور عقار إن اسيتيل سيستين على هذه الأنابيب المصابة. المواد والطرق: تم استخدام 24 فأراً أبيض بالغ بغض النظر عن نوع الجنس وتم تقسيمهم الى 4 مجمو عات. مجمو عة ضابطة ومجموعة إن اسيتيل سيستين بجرعة تعادل جرعة الإنسان البالغ مرتين يوميا ومجموعة اليوروجرافين المجموعة الثالثة عن طريق حقن جرعة عالية من عقار اليوروجر افين 76\% فى وريد الذيل للفئران عن طريق التسريب ومجمو عة اليوروجر افين مع إن اسيتيل سيستين المجمو عة الر ابعة حيث تلقت الفئران نفس الجر عة من عقارى اليوروجر افين و إن اسيتيل سيستين ثم تم فحص العينات التى تم الحصول عليها باستخدام المجهر الضوئى و الإلكترونى. النتائج: أظهرت المجموعتين الضابطة وإن اسيتيل سيستين نفس الصورة النسيجية الطبيعية للأنابيب الكلوية . كما كثفت مجمو عة اليوروجر افين عن توسع أنبوبي مع وجود حطام خلوي في تجويفهم. كما أظهرت بعض الفئ الأنابيب تدميراً

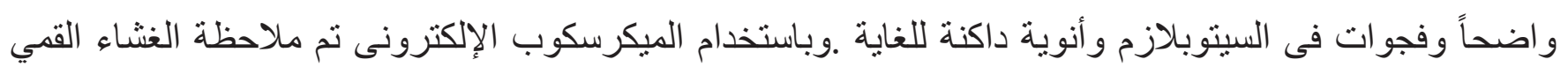

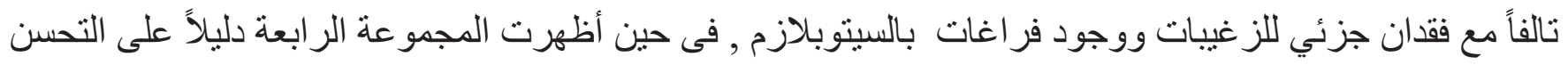
بالمقارنة بالهجموعة الثالثة حيث أظهرت معظم الأنابيب صورة نسيجية طبيعية تقريباً باستثناء عدد قليل من الأنابيب

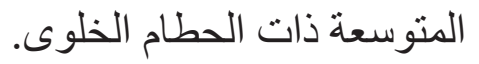
الخلاصة: أن عقار إن اسيتيل سيستين له ناثير وقائي ضد الضرر الكلوى الذى سببه حقن عقار اليوروجر افين لذلك قد

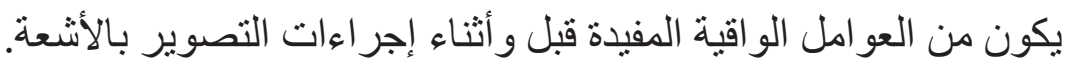

